\title{
Prestorage Temperature and Ultra-low Oxygen Treatments Affect Incidence of Physiological Disorders in Organic 'Granny Smith' Apples
}

\author{
Juan Pablo Zoffoli ${ }^{1}$, Valentina Sanguedolce, Paulina Naranjo, \\ and Carolina Contreras \\ Facultad de Agronomía e Ingeniería Forestal, Pontificia Universidad \\ Católica de Chile, Santiago, Chile
}

Additional index words. superficial scald, bitter pit, lenticel blotch pit, 1-MCP

\begin{abstract}
The physiological disorders superficial scald, bitter pit, and lenticel blotch pit severely compromise the commercial value of 'Granny Smith' apples. A number of chemical treatments are available to alleviate these disorders but they are unacceptable in the expanding organic market. The objective of this research was to study the effectiveness of prestorage treatments - delayed cooling and elevated temperature under ultra-low oxygen (ULO) atmospheres - as organic-friendly strategies to control these disorders. 'Granny Smith' apples were exposed to four different treatments: 1) conditioning temperature treatments (CTemp): 10 days at $3^{\circ} \mathrm{C}$ or 30 days at $3^{\circ} \mathrm{C}$ or 10 days at $20^{\circ} \mathrm{C}$, in air; 2) the same conditioning temperature treatments combined with an ultra-low oxygen (ULO) conditioning treatment of $0.2-0.5 \mathrm{kPa} \mathrm{O}_{2}$ and $<0.5 \mathrm{kPa} \mathrm{CO} \mathrm{CO}_{2}$;) 1-methylcyclopropene (1-MCP) treatment as a commercial control; and 4) untreated control fruit. After the prestorage treatment, fruit were stored for 90 or 150 days at $0{ }^{\circ} \mathrm{C}$, and then held poststorage for 8 days at $20{ }^{\circ} \mathrm{C}$ before quality analysis. A combination treatment of temperature conditioning and ULO for 30 days at $3{ }^{\circ} \mathrm{C}$ achieved the best control of superficial scald, bitter pit, and lenticel blotch pit. The use of ULO with CTemp for 10 days at $20^{\circ} \mathrm{C}$ offered the same control but induced high concentrations of ethanol and acetaldehyde that affected the organoleptic acceptability of the fruit and reduced its commercial value. The use of 1-MCP offered $100 \%$ control of superficial scald but bitter pit and lenticel blotch pit disorder incidences were similar or higher than in the control fruit. All ULO conditioning treatments resulted in high ethanol and acetaldehyde concentrations during the first 90 days of storage, but fruit exposed to ULO conditioning treatment for 30 days at $3{ }^{\circ} \mathrm{C}$ showed similar organoleptic acceptability to control fruit after 150 days. Therefore, ULO conditioning is a potentially useful treatment for the organic apple industry.
\end{abstract}

'Granny Smith' is the most common green apple cultivar in the world. However, it is highly susceptible to physiological disorders such as superficial scald and bitter pit (Mitcham et al., 1996). These disorders reduce the effective storage time and make 'Granny Smith' production highly dependent on the use of chemical treatments. Bitter pit is a physiological disorder associated with low calcium concentration in the fruit. Currently, the only effective method for controlling bitter pit consists in several preharvest and postharvest calcium spray applications (Ferguson and Watkins, 1989). In many parts of the world, superficial scald has been controlled or alleviated commercially with diphenylamine (DPA) applications (Little et al., 2000).

With the recent ban on the use of DPA by the European Union (EU), with a maximum

\footnotetext{
Received for publication 21 June 2018. Accepted for publication 8 Aug. 2018.

We gratefully acknowledge the partial financial support of Copefrut Export.

'Corresponding author. E-mail: zoffolij@uc.cl.
}

antioxidants, and ventilation, all of which are extensively reviewed in Lurie and Watkins (2012).

Organic production has increased steadily in the last two decades in the United States and has particularly expanded in the apple market. Apples are among the top three most preferred products purchased by consumers of organic foods, with 'Granny Smith' being the fifth most produced organic apple (U.S. Department of Agriculture Economic Research Service, 2011). Organic production has also recently become important in Chile, where, during 2016, the exported volume rose sharply by $40 \%$. Organic apples in Chile account for $\approx 1200$ planted hectares, with 'Granny Smith' the third most-produced organic cultivar (ODEPA, 2017). In the southern hemisphere, organic apple harvest starts in March and export of fruit to the northern hemisphere extends to June. Superficial scald limits the extent of this export market window, as the opportunity for commercialization of organic 'Granny Smith' is limited to $90 \mathrm{~d}$ of storage before the appearance of the symptoms of the disorder.

The organic market is highly restrictive in terms of the use of chemicals, which makes the storage of organic apples a particular challenge. Products frequently used in conventional apples, such as DPA and 1-MCP, are not allowed for organic apples. Additionally, 1-MCP may increase bitter pit and lenticel blotch pit (Calvo and Cardan, 2010; Gago et al., 2015). Likewise, the traditional concentrations of $\mathrm{O}_{2}$ and $\mathrm{CO}_{2}$ of $\mathrm{CA}(1.5 \mathrm{kPa}$ $\mathrm{O}_{2} ; 1 \mathrm{kPa} \mathrm{CO}_{2}$ ) are not sufficient for the control of superficial scald (Lau, 1990). This situation means researchers must look for alternative non-chemical interventions.

Organic-friendly strategies for the control of superficial scald include ULO and ILO, DCA and, recently, the combination of low oxygen and high temperature for short periods (Pesis et al., 2010). However, few studies have investigated the interaction between low oxygen and different temperatures. In the search for non-chemical alternatives to extend the storage life of organic apples by controlling superficial scald, bitter pit, and lenticel blotch pit, we investigated interactions between different conditioning temperature and low oxygen treatments.

\section{Materials and Methods}

( which reduces superficial scald (Wang and Dilley, 2000) and its variants initial low oxygen (ILO) (Wang and Dilley, 1999; Zanella, 2003) and dynamic atmosphere storage (DCA) (Zanella et al., 2005); and 3) delayed cooling treatments (also known as prestorage conditioning treatments), such as warming before or during cold storage (Alwan and Watkins, 1999), or stepwise cooling (Moggia et al., 2009). All of these technologies either greatly reduce $\alpha$-farnesene synthesis and accumulation (1-MCP and ULO) or prevent $\alpha$-farnesene oxidation (DPA and ULO). Many other technologies have been reported, such as ethanol vapor treatment, intermittent warming, coatings,

\section{Plant material and treatments}

On 29 Mar. 2016, 'Granny Smith' apples were selected for uniformity and freedom from blemishes from a group of five $350 \mathrm{~kg}$ plastic bins in a packhouse. This was done as a commercial organic orchard in Quinta Tilcoco in the Central Valley, Chile $\left(34^{\circ} 22^{\prime} 11.84^{\prime \prime} \mathrm{S}, 70^{\circ} 50^{\prime} 59.20^{\prime \prime} \mathrm{W}\right)$.

A total of 5680 fruit $(\approx 600 \mathrm{~kg})$ were transported $300 \mathrm{~km}$ to the Postharvest Laboratory of the Catholic University of Chile. Fruit was stored overnight at $20^{\circ} \mathrm{C}$ before treatments were applied. Initial fruit maturity was assessed on 80 randomly-selected fruit soon as the fruit arrived from harvest from 
and the remainder were grouped randomly into four sets of 2100, 2100, 700, and 700 . These fruit sets were then treated differently. One set of 2100 fruit was "prestorage" treated in an air atmosphere at one of three conditioning temperatures (CTemp) (700 fruit at each temperature). The three CTemp treatments were 1) $10 \mathrm{~d}$ at $\left.3{ }^{\circ} \mathrm{C}, 2\right) 30 \mathrm{~d}$ at $3{ }^{\circ} \mathrm{C}$, or 3) $10 \mathrm{~d}$ at $20^{\circ} \mathrm{C}$. The second set of 2100 fruit was conditioned at the same three temperatures (700 fruit at each) while under an ULO conditioning treatment with a partial pressure of oxygen of $0.2-0.5 \mathrm{kPa}$ and $\mathrm{CO}_{2}$ partial pressure of $<0.5 \mathrm{kPa}$. One set of 700 fruit was treated with 1-MCP and one set of 700 fruit served as the untreated control.

ULO conditioning treatments were placed in open $200 \mathrm{~L}$ plastic containers for $24 \mathrm{~h}$ to reach the desired temperature $\left(3^{\circ} \mathrm{C}\right.$ or $\left.20^{\circ} \mathrm{C}\right)$, then containers were sealed and the desired partial oxygen pressure was obtained by replacing the air (initially $21 \mathrm{kPa}$ ) with 100 $\mathrm{kPa} \mathrm{N} \mathrm{N}_{2}$, dispensed from a nitrogen cylinder (Indura S.A., Santiago, Chile). Each ULO conditioning treatment was applied using four replications of 175 fruit, each in separate container. The oxygen partial pressure was adjusted manually by flushing with nitrogen (to lower it) or with air (to raise it).

On one occasion, two independent containers leaked, but the partial pressures of $\mathrm{O}_{2}$ and $\mathrm{CO}_{2}$ were rapidly restored. Meanwhile, the $\mathrm{CO}_{2}$ partial pressure was maintained low $(<1 \mathrm{kPa})$ using hydrated lime. Each container was provided with a sampling port with a septum attached. During the ULO condition treatments, a sample of $200 \mathrm{~mL}$ was obtained with a syringe, and the $\mathrm{O}_{2}$ and $\mathrm{CO}_{2}$ in the free space of the containers were determined every two days. The $\mathrm{CO}_{2}$ and $\mathrm{O}_{2}$ were checked with a portable MAP 4000 analyzer (Hitech Instruments Ltd., Luton, UK) with zirconia and katharometer sensors, respectively.

For the 1-MCP treatment, four boxes with 175 fruit in each were exposed to $625 \mathrm{~nL} \cdot \mathrm{L}^{-1}$ 1 -MCP ( $1 \mathrm{~g} \cdot \mathrm{m}^{-3}$, powder $0.14 \%$, SmartFresh; AgroFresh, Collegeville, PA) for $24 \mathrm{~h}$ at $20{ }^{\circ} \mathrm{C}$ in a closed chamber.

After all the treatments (ULO conditioning, CTemp, 1-MCP) were applied, fruit were packed in four $19 \mathrm{~kg}$ boxes per treatment with perforated plastic liner bags and stored at $0 \pm$ $0.5{ }^{\circ} \mathrm{C}$ for up to $150 \mathrm{~d}$ followed by an additional ripening period of $8 \mathrm{~d}$ at $20{ }^{\circ} \mathrm{C}$. Fruit without treatment were packed in four boxes with perforated plastic liner bags, 175 fruit in each, and left as controls and stored directly at $0{ }^{\circ} \mathrm{C}$ for the same period of time.

\section{Fruit chemical analyses}

$\alpha$-farnesene and conjugated trienol concentrations in the apple peel tissue. The

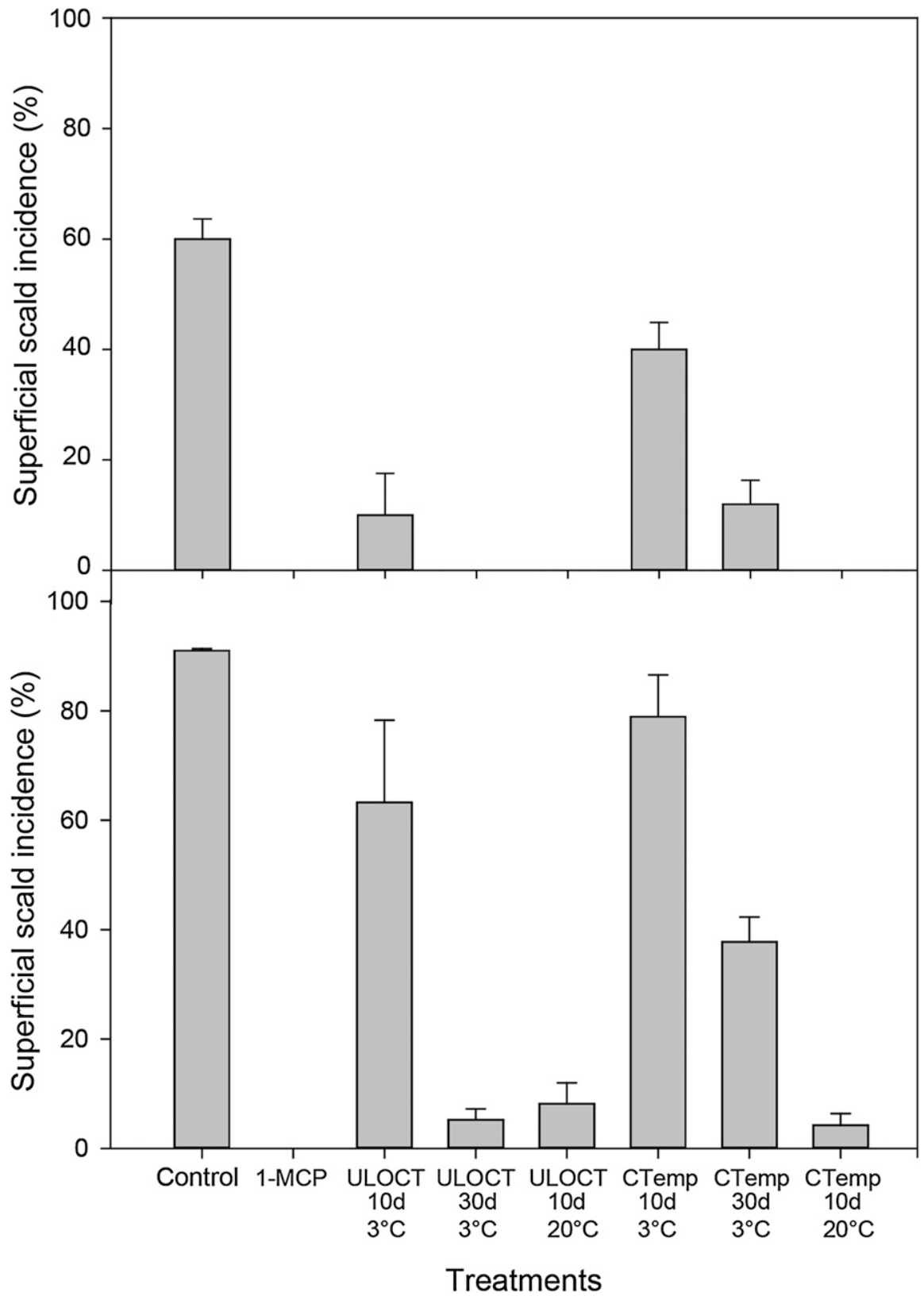

Fig. 1. The effect of conditioning temperature treatments $(\mathrm{CTemp}) 10 \mathrm{~d}$ at $3{ }^{\circ} \mathrm{C}$ or $30 \mathrm{~d}$ at $3{ }^{\circ} \mathrm{C}$ or $10 \mathrm{~d}$ at $20^{\circ} \mathrm{C}$ and ultra low oxygen conditioning treatments (ULOCT) $10 \mathrm{~d}$ at $3^{\circ} \mathrm{C}$ or $30 \mathrm{~d}$ at $3{ }^{\circ} \mathrm{C}$ or $10 \mathrm{~d}$ at $20^{\circ} \mathrm{C}$. Control and $1-$ MCP on superficial scald obtained on 'Granny Smith' apples after $90 \mathrm{~d}$ (top) and $150 \mathrm{~d}$ (bottom) at $0{ }^{\circ} \mathrm{C}$, plus $8 \mathrm{~d}$ at $20^{\circ} \mathrm{C}$. Values are means \pm standard error, $n=4$ replicates of 20 fruit treated in four separate containers.

Table 1. Fruit quality parameters of 'Granny Smith' apples after 90 and $150 \mathrm{~d}$ at $0{ }^{\circ} \mathrm{C}$ plus $8 \mathrm{~d}$ of ripening at $20^{\circ} \mathrm{C}$.

\begin{tabular}{|c|c|c|c|c|c|c|}
\hline \multirow[b]{2}{*}{ Treatments } & \multicolumn{3}{|c|}{$90 \mathrm{~d}$ at $0{ }^{\circ} \mathrm{C}+8 \mathrm{~d}$ at $20^{\circ} \mathrm{C}$} & \multicolumn{3}{|c|}{$150 \mathrm{~d}$ at $0{ }^{\circ} \mathrm{C}+8 \mathrm{~d}$ at $20^{\circ} \mathrm{C}$} \\
\hline & Acceptability $(0-9)^{z}$ & Firmness $(\mathrm{N})$ & Color $\left(b^{*}\right)$ & Acceptability (0-9) & Firmness $(\mathrm{N})$ & Color $\left(b^{*}\right)$ \\
\hline 1-MCP & $4.7 \mathrm{e}$ & $71.4 \mathrm{e}$ & $40.6 \mathrm{a}$ & $4.46 \mathrm{e}$ & $66.5 \mathrm{~d}$ & $43.2 \mathrm{a}$ \\
\hline ULOCT $10 \mathrm{~d} 20^{\circ} \mathrm{C}$ & $3.1 \mathrm{ab}$ & $70.5 \mathrm{de}$ & $42.4 \mathrm{bcd}$ & $3.16 \mathrm{~cd}$ & $62.0 \mathrm{c}$ & $44.4 \mathrm{bc}$ \\
\hline CTemp $10 \mathrm{~d} 3{ }^{\circ} \mathrm{C}$ & $3.9 \mathrm{bcd}$ & $60.6 \mathrm{~b}$ & $43.5 \mathrm{de}$ & $2.55 \mathrm{ab}$ & $53.0 \mathrm{~b}$ & $44.6 \mathrm{bc}$ \\
\hline CTemp $30 \mathrm{~d} 3{ }^{\circ} \mathrm{C}$ & $3.8 \mathrm{bc}$ & $58.4 \mathrm{~b}$ & $43.7 \mathrm{e}$ & $2.72 \mathrm{bc}$ & $53.9 \mathrm{~b}$ & $45.1 \mathrm{c}$ \\
\hline
\end{tabular}

${ }^{\mathrm{z}}$ Acceptability scale: $0=$ slightly acceptable; $9=$ very acceptable.

${ }^{\mathrm{y}}$ Fisher's least significant difference test was used for multiple comparison analysis of averages. Numbers in a column followed by different letters are significantly different $(P \leq 0.05)$.

$\mathrm{ULOCT}=$ ultra low oxygen conditioning treatment; CTemp $=$ conditioning treatment under air atmosphere. 
$\alpha$-farnesene and conjugated trienes (most of them as conjugated trienols, Rowan et al., 2001) from the apple peel tissue were extracted and quantified after 10,30,60, 90, and $150 \mathrm{~d}$ of storage following the methodology proposed by Zoffoli et al. (1998). Two skin disks $\left(50 \mathrm{~mm}^{2}\right)$ per fruit were obtained randomly from opposite sides of the cheeks of 10 fruit ( 20 disks) per replicate and immersed in $10 \mathrm{~mL}$ of $99 \%$ hexane (Avantor, Phillipsburg, NJ) for $25 \mathrm{~min}$ at room temperature $\left(20\right.$ to $\left.22^{\circ} \mathrm{C}\right)$. The extract was transferred to a $10 \mathrm{~mL}$ tube before spectrophotometric analysis. Each sample was measured using quartz cuvettes on the spectrophotometer (Genesys 2; Spectronic ${ }^{\circledR}$, Leeds, UK) at five wavelengths, 232, 258, 269, 281, and $290 \mathrm{~nm}$. The difference between the absorbance at $281 \mathrm{~nm}$ and that at $290 \mathrm{~nm}$ was determined and the concentration of conjugated trienols $\left(\mathrm{OD}_{281-290}\right)$ was calculated using a molar extinction coefficient of 25,000. The $\alpha$-farnesene concentration was quantified from the absorbance at $232 \mathrm{~nm}$ using a molar extinction coefficient of 27,700.

Internal ethanol, acetaldehyde, and ethylene concentration. The concentration of ethanol and acetaldehyde in the fruit was determined according to Mitcham and McDonald (1993). In brief, $10 \mathrm{~mL}$ of apple juice was obtained from ten apples per replicate. Two slices per apple were used, and each slice weighed $\approx 25 \mathrm{~g}$. The pooled sample of 10 apples (20 slices) was processed in a blender to obtain the apple juice. The $10 \mathrm{~mL}$ apple juice was then mixed with $2 \mathrm{~g}$ of sodium chloride $(\mathrm{NaCl})$ and sealed in a $22 \mathrm{~mL}$ glass vial. The mixture was then homogenized by vortex for $1 \mathrm{~min}$. Samples were incubated in a thermostatic bath at $60{ }^{\circ} \mathrm{C}$ for $40 \mathrm{~min}$ before removal of $500 \mu \mathrm{L}$ of the headspace gas with the aid of a syringe, which was injected into a gas chromatograph (GC2014; Shimadzu Corp., Kyoto, Japan) equipped with a flame ionization detector (FID) at $250{ }^{\circ} \mathrm{C}$ with $\mathrm{N}_{2}$ as the carrier gas. The capillary column was a RTX-5 at $50{ }^{\circ} \mathrm{C}$ (length $30 \mathrm{~m}$, inner diameter $0.32 \mathrm{~mm}$ and $0.25 \mu \mathrm{m}$ film thickness;Resteck Corp., Bellefonte, PA). Acetaldehyde and ethanol were identified at 1.17 and $1.22 \mathrm{~min}$, respectively, and quantified by comparison with peak areas of standard solutions from gas samples extracted after incubation following the same procedure described above. The internal ethylene concentrations of groups of two apples per replicate were determined by air sampling following vacuum extraction of the apples under water (Beyer and Morgan, 1970). The air sample was injected into a GC 8340 chromatograph (Fisons Instruments Inc., Beverly, MA) equipped with a glass column ( $2 \mathrm{~m}$ long, $1 / 4$ " external and $2 \mathrm{~mm}$ internal diameter) filled with Chromosorb 102 (80/100 mesh; Thermo Electron Corporation, Milan, Italy) and a FID detector at $250{ }^{\circ} \mathrm{C}$ using $\mathrm{He}$ as the carrier gas.

External and internal physiological disorder assessments. The external and internal fruit quality were assessed after 90 and $150 \mathrm{~d}$ at
$0{ }^{\circ} \mathrm{C}$ plus $8 \mathrm{~d}$ at $20{ }^{\circ} \mathrm{C}$, using 20 fruit per replication at each evaluation time. The incidence and severity of scald were evaluated following the procedure described by Contreras et al. (2008). External symptoms of physiological disorders (bitter pit and lenticel blotch pit) were assessed following the description of the symptoms published in Tree Fruit Research \& Extension Center, Cullage Assessment \& Education (2007).

Internal browning was evaluated by cutting apples transverse to the longitudinal axis at the middle. The most affected half was evaluated for severity and incidence of the

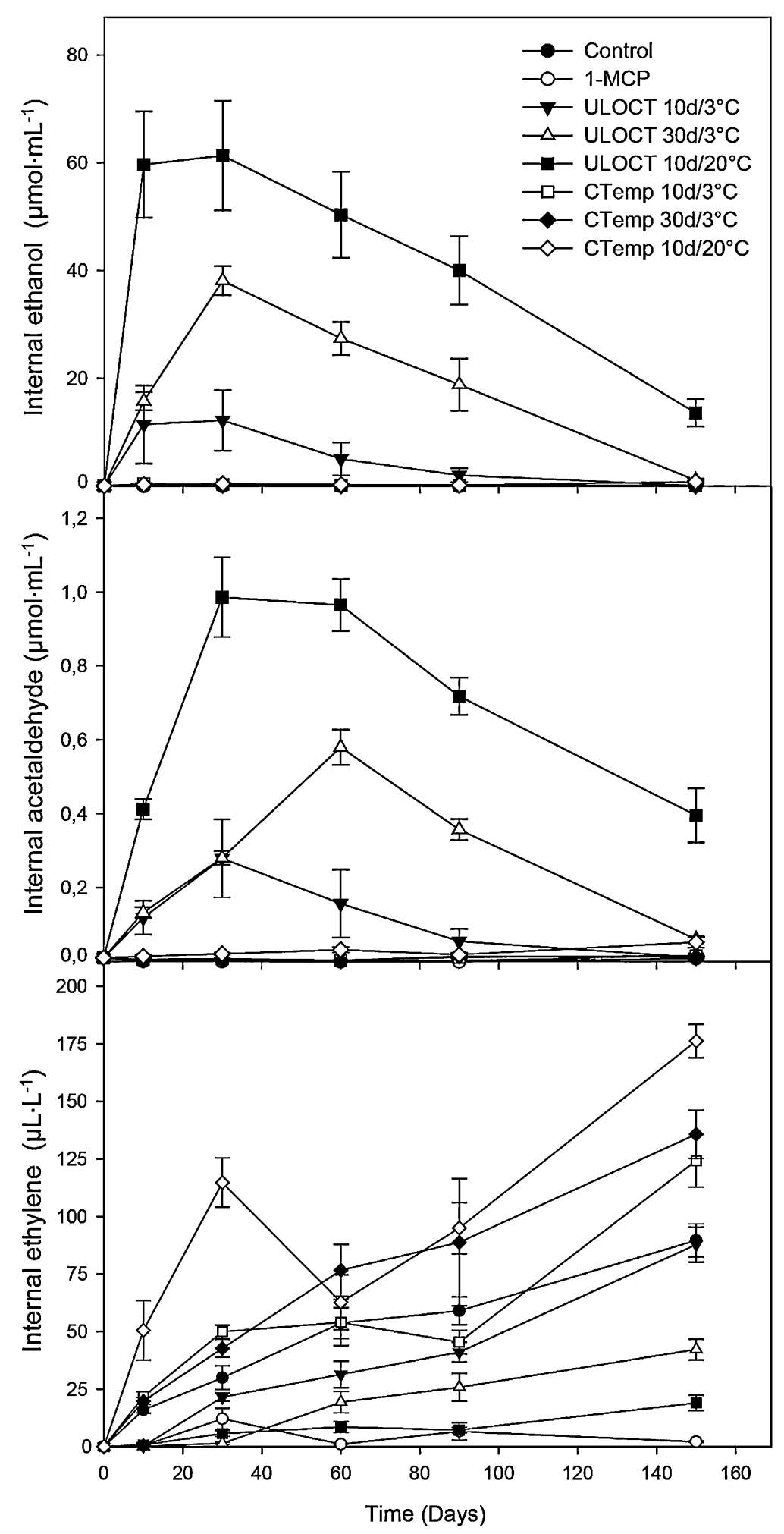

Fig. 2. Internal concentrations of ethanol (top), acetaldehyde (middle), and ethylene (bottom) in 'Granny Smith' apples after $150 \mathrm{~d}$ at $0{ }^{\circ} \mathrm{C}$. Values are means \pm standard error, $n=4$ replicates treated in four separate containers. ULOCT $=$ ultra low oxygen conditioning treatment; CTemp $=$ conditioning temperature treatment under air atmosphere. 
disorder. The visual relative scale used for intensity of internal browning was $1=$ light, $2=$ moderate, and $3=$ severe (Contreras et al., 2008).

Fruit quality assessments. Starch content was rated visually $(1=$ immature, $10=$ overmature) (Ctifl, Paris, France) at harvest after staining with an iodine solution the cut surface of half an apple. Firmness was determined with a penetrometer (model FT 327; Effegi, Milan, Italy) fitted with an $11.1 \mathrm{~mm}$ plunger at opposite sides of the equatorial region of each fruit. Soluble solids (SS) and titratable acidity (TA) were measured in 5 $\mathrm{mL}$ fresh juice using, respectively, a digital refractometer (Atago PAL-1; Atago, Tokyo, Japan) and a pH-meter pH211 (Hanna Instruments, Woonsocket, RI) titrating with 0.1 $\mathrm{N} \mathrm{NaOH}$ to $\mathrm{pH} 8.2$. The peel color was assessed using $L^{*}, a^{*}, b^{*}$, and hue values with a colorimeter (CR-400; Minolta, Osaka, Japan) under CIE illuminant $\mathrm{D}_{65}$ conditions. The $b^{*}$ value was reported to describe the change from green to yellow.

The fruit were harvested at starch index value of 5.6, with $82.7 \mathrm{~N}$ of firmness, $0.6 \%$ titratable acidity, and the green color of the skin was $L^{*}$ : $68.5 \%$ with a hue value of $116.3^{\circ}$.

A total of five fruit were considered for evaluation of firmness and soluble solids after removal from storage at $0{ }^{\circ} \mathrm{C}$ at 90 and $150 \mathrm{~d}$ and 8 additional days at $20^{\circ} \mathrm{C}$. Sensory perception of the treatments was assessed by eight trained panelists. Panelists were asked to judge texture and flavor acceptability using a discontinuous, nine point scale which ranged from 0 (dislike) to 9 (like extremely) (Marin, 2002). The time between removal from storage and sensory assessment was $6 \mathrm{~h}$. Apples were cut using an apple slicer (Sierra, Amazon, USA) and each slice was served one at the time. Acceptability was taken into consideration using the average value of the sensory data from the fruit of each of the four replications.

\section{Statistical analyses}

The experiment was conducted in a completely randomized design. The three conditioning temperatures were established in different chambers, and the ULO atmospheres were provided in separate containers using four containers with 175 fruit per each temperature conditioning treatment. Therefore, a total of 12 containers were used, and no formal replications of the temperature chambers were used in the experiment.

In the case of 1-MCP treatment, the application was done in one chamber and the fruit was distributed in four boxes of 175 fruit each without formal replications. In addition, four boxes of control treatment were also stored directly in a $0{ }^{\circ} \mathrm{C}$ chamber.

Fruit quality attributes and physiological disorders were measured in 20 fruit per replicate at each time of evaluation. All statistical analyses were carried out using Infostat 2016 (Infostat Group, Cordoba, Argentina). Analysis of variance was carried out and Fisher's least significant difference multiple comparison test was used to compare means with $P \leq 0.05$.

\section{Results and Discussion}

Prestorage delays used as conditioning treatments, at higher temperatures or extended times of conditioning, are effective in reducing superficial and soft scald in apples (Moggia et al., 2009; Watkins et al., 2004). Conditioning has also been shown to be effective in reducing mealiness in peaches and nectarines (Crisosto et al., 2004). Different alternatives to temperature management to reduce scald in 'Granny Smith' apples have been proposed. Keeping the fruit at $10{ }^{\circ} \mathrm{C}$ for $10 \mathrm{~d}$ before storage at $0{ }^{\circ} \mathrm{C}$ did not reduce scald incidence, but warming for $5 \mathrm{~d}$ at $20^{\circ} \mathrm{C}$ after $7 \mathrm{~d}$ or $28 \mathrm{~d}$ of storage at $0{ }^{\circ} \mathrm{C}$ did reduce scald (Watkins et al., 1995). Moreover, adding a period of $20 \mathrm{~d}$ at $4{ }^{\circ} \mathrm{C}$ to the initial $10 \mathrm{~d}$ at $10^{\circ} \mathrm{C}$ eliminated the scald completely (Moggia et al., 2009).

In our study, various conditioning treatments were effective, with the results depending on the temperature and the period of treatment (Fig. 1). The best conditioning treatment was $10 \mathrm{~d}$ at $20{ }^{\circ} \mathrm{C}$ for a storage period of $150 \mathrm{~d}$. This treatment was effective at reducing scald to $<10 \%$, compared with the control where more than $90 \%$ of fruit had scald, confirming the results of Pesis et al. (2010). However, the CTemp of $10 \mathrm{~d}$ at $20^{\circ} \mathrm{C}$ generated significant yellowing of the fruit, reducing their acceptability (Table 1). CTemp for $10 \mathrm{~d}$ at $3{ }^{\circ} \mathrm{C}$ did not control scald, but when the time increased to $30 \mathrm{~d}$ at $3{ }^{\circ} \mathrm{C}$ scald incidence decreased considerably. Nevertheless, incidence was still high, compared with a CTemp of $10 \mathrm{~d}$ at $20^{\circ} \mathrm{C}$. Compared with CTemp only, ULO treatments combined with a conditioning temperature lowered the incidence of scald much more effectively. This agrees with previous studies where low oxygen in storage atmospheres prevents the development of the disorder. It would seem that scald is associated with oxidative stress, with radical-forming compounds being proposed as principally responsible for the tissue damage (Rao et al., 1998; Whitaker, 2004; Sabban-Amin et al., 2011) (Fig. 1). ULO conditioning treatment at $20{ }^{\circ} \mathrm{C}$ reduced the incidence of scald; however, the treatment still showed the lowest acceptability scores in the fruit (Table 1). This was accompanied by higher amounts of ethanol and acetaldehyde in the fruit tissue (Fig. 2). Similarly, the reduction of scald improved when a CTemp of $30 \mathrm{~d}$ at $3{ }^{\circ} \mathrm{C}$ was combined with ULO (Fig. 1); this fruit also showed low levels of ethanol and acetaldehyde, decreased yellowing as a consequence of the low oxygen, and lower ethylene production (Fig. 2). Therefore, ULO conditioning treatment of $30 \mathrm{~d}$ at $3{ }^{\circ} \mathrm{C}$ was the best treatment for the control of scald.

Accumulation of ethanol produced by short storage periods under ULO conditioning treatments was induced by anaerobic respiration (Fig. 2). Compared with the other treatments, ethanol concentrations were higher in ULO conditioning treatments, in the following order: ULO conditioning treatment of $10 \mathrm{~d}$ at $20{ }^{\circ} \mathrm{C}>\mathrm{ULO}$ conditioning treatment of $30 \mathrm{~d}$ at $3{ }^{\circ} \mathrm{C}>\mathrm{ULO}$ conditioning treatment of $10 \mathrm{~d}$ at $3{ }^{\circ} \mathrm{C}$. Ethanol vapor has proven effective in reducing scald, even when the fruit is subsequently stored in regular air (Ghahramani et al., 2000). Also, in ILO treatment before CA storage, scald incidence is reduced only when the oxygen partial pressure is low

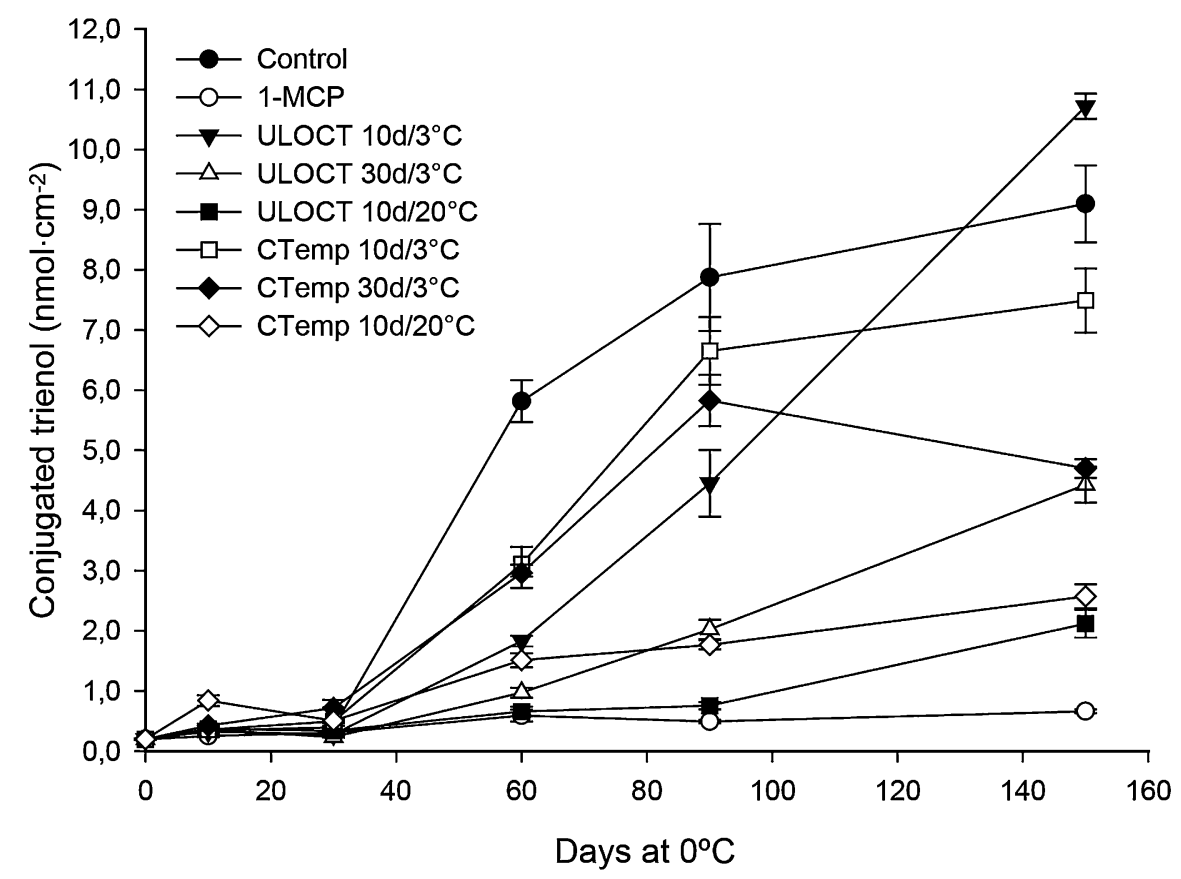

Fig. 3. Concentration of conjugated trienols after $150 \mathrm{~d}$ at $0{ }^{\circ} \mathrm{C}$ in 'Granny Smith' apples. Values are means \pm standard error, $n=4$ replicates of 20 fruit treated in four separate containers. ULOCT $=$ ultra low oxygen conditioning treatment; CTemp = conditioning temperature treatment under air atmosphere. 
enough to initiate anaerobic respiration and sufficient ethanol accumulates in the tissue (Wang and Dilley, 2000). Ethanol has been proposed as a free radical scavenger (Halliwell and Gutteridge, 2007) and was associated with a slower decline in reducing substances and enzyme activities associated with the ascorbate-glutathione cycle by reducing oxidative stress and increasing the activities of peroxidase, catalase, and superoxide dismutase in broccoli (Mori et al., 2009). Based on our results, the accumulation of ethanol with low oxygen stress makes it difficult to interpret the direct effects of ethanol on scald development.

Conjugated trienol concentrations were affected by the treatments during storage (Fig. 3). Although sometimes the correlation has been weak (Whitaker et al., 2000), they have been proposed as likely associated with scald in 'Granny Smith' (Rowan et al., 2001). Similarly, the compound 6-methyl-5-hepten2-one, a major volatile secondary product of $\alpha$-farnesene autoxidation (Rowan et al., 2001), is also released during in vitro autoxidation of conjugated trienols (Whitaker and Saftner, 2000). 6-methyl-5-hepten-2-one is indicative of free-radical mediated reactions. The control ULO conditioning treatment and CTemp for $10 \mathrm{~d}$ at $3{ }^{\circ} \mathrm{C}$ treatments showed the highest values of conjugated trienols after $150 \mathrm{~d}$ of storage, and also presented the highest incidences of scald. The 1-MCP treatment showed the lowest concentrations of conjugated trienols after $150 \mathrm{~d}$ of storage (Fig. 3) and fully alleviated scald (Fig. 1). The low concentration of conjugated trienols and the alleviation of scald corroborate the claim that 1-MCP is one of the best chemical alternatives for scald, as previously reported (Lurie and Watkins, 2012).

Similarly, ULO conditioning treatment of $10 \mathrm{~d}$ at $20^{\circ} \mathrm{C}$ suppressed the production of conjugated trienols and the internal production of ethylene, with total control of scald at ripening after 90 and $150 \mathrm{~d}$ of storage. However, the same treatment without ULO had the same level of scald, but with a considerably higher internal concentration of ethylene, and maintained the suppression of conjugated trienols formation; therefore, other mechanisms different from ethylene may be involved in the scald development. For instance, Alwan and Watkins (1999) suggested that less accumulation of conjugated trienols was detected when a warming period during storage was used to ameliorate scald development (this study was not carried out with 'Granny Smith').

The efficacy of the CTemp and ULO conditioning treatments in controlling scald may be attributable to the induction of high metabolic activity that may remove toxic or inhibitory substances that accumulate under oxidative stress. Such oxidative activity would be induced at low temperatures, as proposed by Lu et al. (2011) and Watkins et al. (1995). Reactive oxygen species (ROS), including - $\mathrm{OH}, \mathrm{O}_{2}^{-}, \mathrm{H}_{2} \mathrm{O}_{2}$ and conjugated trienols, from $\alpha$-farnesene oxidation or cell membrane peroxidation are hypothesized to accumulate, disrupting cell membranes and inducing scald symptoms. Several authors (Pesis et al., 2012; Rao et al., 1998; SabbanAmin et al., 2011), using different detection methods, have demonstrated that the accumulation of ROS was much lower in fruit under low oxygen conditions $(<1 \mathrm{kPa})$.

Two external symptoms of physiological disorders, bitter pit and lenticel blotch pit, appeared at ripening after 90 and $150 \mathrm{~d}$ of storage. Interestingly, the ULO conditioning $\left(10 \mathrm{~d}\right.$ at $20^{\circ} \mathrm{C}$ and $30 \mathrm{~d}$ at $\left.3{ }^{\circ} \mathrm{C}\right)$ and CTemp $\left(10 \mathrm{~d}\right.$ at $\left.20^{\circ} \mathrm{C}\right)$, the most effective treatments against scald, also controlled bitter pit and lenticel blotch pit disorders. However, control and 1-MCP treatments resulted in a high incidence of these two disorders. 1-MCP treatment shows the expression of the disorder earlier in storage and with a higher proportion of fruit with symptoms of lenticel

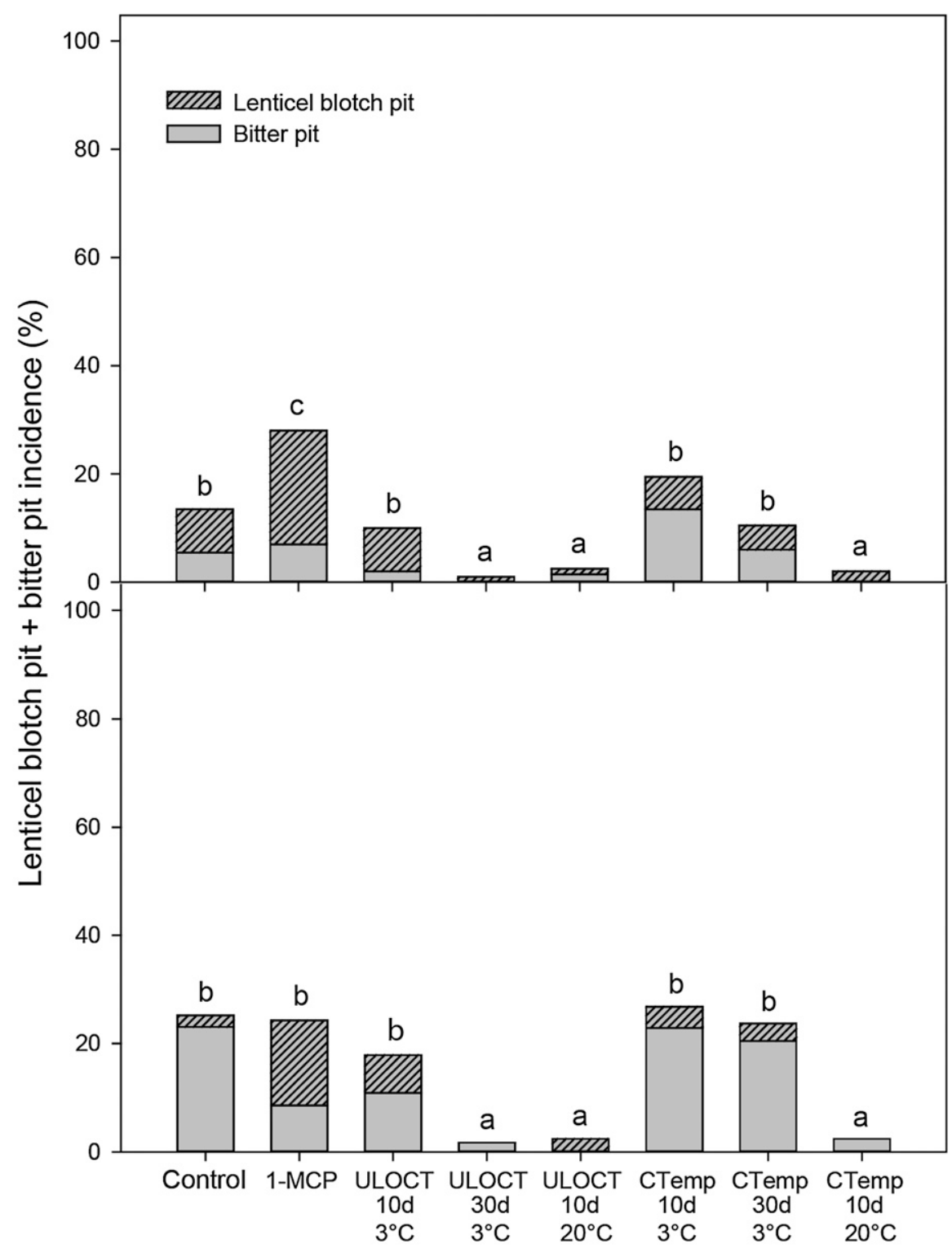

Fig. 4. Incidence of bitter pit and lenticel blotch pit in 'Granny Smith' apples after $90 \mathrm{~d}$ (top) and $150 \mathrm{~d}$ (bottom) at $0{ }^{\circ} \mathrm{C}$, plus $8 \mathrm{~d}$ at $20^{\circ} \mathrm{C}$. Values are means, $n=4$ replicates of 20 fruit treated in four separate containers. Means with different letters are significantly different according to Fisher's least significant difference multiple comparison test $(P \leq 0.05)$. ULOCT $=$ ultra low oxygen conditioning treatment; $\mathrm{CTemp}=$ conditioning temperature treatment under air atmosphere. blotch pit than bitter pit (Fig. 4). As previously reported, 1-MCP did not control bitter pit in 'Golden Delicious' apples from some orchards (Gago et al., 2015) and it has been observed to increase lenticel blotch pit (Calvo and Cardan, 2010). We found that ULO conditioning treatment of $30 \mathrm{~d}$ at $3{ }^{\circ} \mathrm{C}$ and CTemp $10 \mathrm{~d}$ at $20^{\circ} \mathrm{C}$ had similar effects on control of disorders in 'Granny Smith'. However, the acceptability and yellowing render the latter treatment commercially inadequate, as was discussed with scald.

These results confirm previous reports (Pesis et al., 2010; Val et al., 2010) and open up a new way for managing these types of physiological disorders, the incidences of which are generally attributed to calcium deficiency, with conventional interventions based on remediation of the deficit. The 
best effects were associated with ULO conditioning treatment and CTemp at high temperatures, and therefore further research is warranted to demonstrate if ethanol is, or is not, directly involved in the reduction of these disorders.

Prestorage delayed cooling and elevated temperatures under ultra-low oxygen had significant effects at the metabolite level (conjugated trienols, ethanol, and ethylene). Although ULO conditioning treatments were applied for a short period of time (e.g., $10 \mathrm{~d}$ at $20{ }^{\circ} \mathrm{C}$ or $30 \mathrm{~d}$ at $3{ }^{\circ} \mathrm{C}$ ), the ULO effect was observed at a disorder level for up to $150 \mathrm{~d}$.

Many years of research are needed to establish a new storage protocol. Here we have studied an alternative for the postharvest handling of physiological disorders in 'Granny Smith' apple for the organic market. Other protocols that have been successful in the past to alleviate physiological disorders include those affecting the incidence of soft scald (Watkins et al., 2004) and CA-related injuries (Contreras et al., 2014) in 'Honeycrisp' apples. Before a new protocol can be adopted by the industry, other aspects, such as commercial practicability, cost, and variability of results must be taken into account. ULO conditioning treatment can be applied postharvest in conventional CA rooms; various combinations of time and temperature may allow shortening of the treatment times and thus reductions in cost. However, since ULO is a stress condition where oxygen levels stay close to the anaerobic compensation point, a non-destructive measurement of ethanol is needed for commercial use, similar to what has been used for DCA storage based on chlorophyll fluorescence monitoring (Zanella et al., 2005), or dynamic control system (DCS), which uses ethanol measurements in the headspace of a small box of sample fruit inside the ULO chamber (Veltman et al., 2003), or the method based on the measurement of respiratory quotient (RQ-DCA) (Bessemans et al., 2016). In the future, the production of ethanol and other metabolic changes may serve as disorder markers, not only for scald incidence, but also for early detection of calcium-related disorders. For instance, bitter pit and lenticel blotch pit disorders may be present at two phases, one at preharvest where the induction occurs, and the other at the postharvest where it may be expressed, depending on postharvest managements - as demonstrated by delayed storage using temperature and low oxygen.

\section{Literature Cited}

Alwan, T.F. and C.B. Watkins. 1999. Intermittent warming effects on superficial scald development of 'Cortland', 'Delicious' and 'Law Rome' apple fruit. Postharvest Biol. Technol. 16:203-212.

Bessemans, N., P. Verboven, B.E. Verlinden, and B.M. Nicolai. 2016. A novel type of dynamic controlled atmosphere storage based on the respiratory quotient (RQ-DCA). Postharvest Biol. Technol. 115:91-102.
Beyer, E.M., Jr. and P.W. Morgan. 1970. A method for determination the concentration of ethylene in the gas phase of vegetative plant tissues. Plant Physiol. 46:352-354.

Calvo, G. and A.P. Cardan. 2010. 1-Methylcyclopropene (1-MCP) affect physiological disorders in 'Granny Smith' apples depending on maturity stages. Acta Hort. 857:63-69.

Contreras, C., N. Alsmairat, and R. Beaudry. 2014. Prestorage conditioning and diphenylamine improve resistance to controlled-atmosphererelated injury in 'Honeycrisp' apples. HortScience 49:76-81.

Contreras, C., J.P. Zoffoli, J.A. Alcalde, and M. Ayala. 2008. Evolución del daño por insolación de manzanas 'Granny Smith' durante el almacenaje refrigerado. Cien. Inv. Agr. 35:147-157.

Crisosto, C.H., D. Garner, H.L. Andris, and K.R Day. 2004. Controlled delayed cooling extends peach market life. HortTechnology 14:99-104.

EU Pesticides Database. 2012. Review report for the active substance diphenylamine. 21 Dec. 2017. <http://ec.europa.eu/food/plant/pesticides/ eu-pesticides-database/public/?event=activesubstance. detail\&language $=E N \&$ selectedID $=1264>$.

Ferguson, I.B. and C.B. Watkins. 1989. Bitter pit in apple fruit. Hort. Rev. 11:289-355.

Gago, C., A. Guerreiro, M. Graça, and T. Panagopoulos. 2015. Effect of harvest date and 1-MCP (Smartfresh $^{\mathrm{TM}}$ ) treatment on Golden Delicious apple cold storage physiological disorders. Postharvest Biol. Technol. 110:77-85.

Ghahramani, F., K.J. Scott, and R. Holmes. 2000. Effects of alcohol vapors and oxygen stress on superficial scald and red color of stored 'Delicious' apples. HortScience 35:12921293.

Halliwell, B. and J.M.C. Gutteridge. 2007. Cellular responses to oxidative stress: Adaptation, damage, repair, senescence and death, p. 187-267. In: B. Halliwell and J.M.C. Gutteridge (eds.). Free radicals in biology and medicine. 4th ed. Oxford University Press, New York.

Lau, O.L. 1990. Efficacy of diphenylamine, ultralow $\mathrm{O}_{2}$, and ethylene scrubbing on scald control in 'Delicious' apples. J. Amer. Soc. Hort. Sci. 115:959-961.

Little, C.R., J. Faragher, and R.J. Holmes. 2000 Storage technology for apples and pears: A guide to production, postharvest treatment and storage of pome fruit in Australia. Dept. of Natural Resources and Environment, Victoria, Australia.

Lu, X., X. Liu, S. Li, X. Wang, and L. Zhang. 2011. Possible mechanisms of warming effects for amelioration of superficial scald development on 'Fuji' apples. Postharvest Biol. Technol. 62:43-49.

Lurie, S. and C.B. Watkins. 2012. Superficial scald, its etiology and control. Postharvest Biol. Technol. 65:44-60.

Marin, A. 2002. Consumers' evaluation of apple quality. Proc. Washington Tree Fruit Postharvest Conference, Yakima, WA, 12-13 Mar. 2002.

Mitcham, E.J., C.H. Crisosto, and A.A. Kader. 1996. Postharvest Technology Center, UC Davis, Produce Facts: Apple, Granny Smith. Recommendation for Maintaining Postharvest Quality. <http://postharvest.ucdavis.edu/files/ 259401.pdf>.

Mitcham, E.J. and R.E. McDonald. 1993. Respiration rate, internal atmosphere, and ethanol and acetaldehyde accumulation in heat treated mango fruit. Postharvest Biol. Technol. 3:7786.
Moggia, C., O. Hernandez, M. Pereira, G.A. Lobos, and J.A. Yuri. 2009. Effect of the cooling system and 1-MCP on the incidence of superficial scald in 'Granny Smith' apples. Chil. J. Agr. Res. 69:383-390.

Mori, T., H. Terai, N. Yamauchi, and Y. Suzuki. 2009. Effects of postharvest ethanol vapor treatment on the ascorbate-glutathione cycle in broccoli florets. Postharvest Biol. Technol. 52:134-136.

ODEPA. 2017. Organic Agriculture. 7 Oct. 2017. $<$ http://www.odepa.cl/wp-content/uploads/2017/ 11/organico2017Fi>.

Pesis, E., S. Ebeler, S. Tonetto de Freitas, M. Padda, and E.J. Mitcham. 2010. Short anaerobiosis period prior to cold storage alleviates bitter pit and superficial scald in Granny Smith apples. J. Sci. Food Agr. 90:2114-2123.

Pesis, E., O. Feygenberg, L. Goldenberg, and R. Sabban-Amin. 2012. Superficial scald symptoms in 'Granny Smith' apples associated with reactive oxygen species (ROS) accumulation. Proc. Annu. Meet. Fla. State Hort. Soc. 125:276-279.

Rao, M.V., C.B. Watkins, S.K. Brown, and N.F. Weeden. 1998. Active oxygen species metabolism in 'White Angel' $x$ 'Rome Beauty' apple selections resistant and susceptible to superficial scald. J. Amer. Soc. Hort. Sci. 123:299-304.

Rickard, B.J., D.R. Rudell, and C.B. Watkins. 2016. Ex ante economic evaluations of technologies for managing postharvest physiological disorders: The case of 'Empire' apples in New York state. HortScience 51: 537-542.

Rowan, D.D., M.B. Hunt, S. Fielder, J. Norris, and M.S. Sherburn. 2001. Conjugated triene oxidation products of $\alpha$-farnesene induce symptoms of superficial scald on stored apples. J. Agr. Food Chem. 49:2780-2787.

Rupasinghe, H.P.V., D.P. Murr, G. Paliyath, and L. Skog. 2000. Inhibitory effect of 1-MCP on ripening and superficial scald development in 'McIntosh' and 'Delicious' apples. J. Hort. Sci. Biotechnol. 75:271-276.

Sabban-Amin, R., O. Feygenberg, E. Belausov, and E. Pesis. 2011. Low oxygen and 1-MCP pretreatments delay superficial scald development by reducing reactive oxygen species (ROS) accumulation in stored 'Granny Smith' apples. Postharvest Biol. Technol. 62:293304.

Tree Fruit Research \& Extension Center, Cullage Assessment \& Education. 2007. Quick identification guide to apple postharvest defects \& disorders. $<$ http://entomology.tfrec.wsu.edu/Cullage_Site/ Physiol_LBP.html>.

U.S. Department of Agriculture Economic Research Service. 2011. Characteristics of conventional and organic apple production in the United States. 7 Dec. 2017. <www.ers.usda. gov/topics/natural-resources-environment/organicagriculture/s.

Val, J., V. Fernández, P. López, J.M. Peiró, and A. Blanco. 2010. Low oxygen treatment prior to cold storage decreases the incidence of bitter pit in 'Golden Reinders' apples. J. Sci. Food Agr. 90:536-540.

Veltman, R., J. Verschoor, and J.H.R. van Dugteren. 2003. Dynamic control system (DCS) for apples (Malus domestica Borkh, cv. Elstar): Optimal quality through storage based on product response. Postharvest Biol. Technol. 27:79-86.

Wang, Z. and D.R. Dilley. 1999. Control of superficial scald of apples by low-oxygen atmospheres. HortScience 34:1145-1151. 
Wang, Z. and D.R. Dilley. 2000. Initial low oxygen stress controls superficial scald of apples. Postharvest Biol. Technol. 18:201-213.

Watkins, C.B. 2006. The use of 1-methylcyclopropene (1-MCP) on fruits and vegetables. Biotechnol. Adv. 24:389-409.

Watkins, C.B., W.J. Bramlage, and B.A. Cregoe. 1995. Superficial scald of 'Granny Smith' apples is expressed as a typical chilling injury. J. Amer. Soc. Hort. Sci. 120:88-94.

Watkins, C.B., J.F. Nock, S. Weis, S. Jayanty, and R. Beaudry. 2004. Storage temperature, diphenylamine, and pre-storage delay effects on soft scald, soggy breakdown and bitter pit of 'Honeycrisp' apples. Postharvest Biol. Technol. 32:213-221.
Whitaker, B.D. 2004. Oxidative stress and superficial scald of apple fruit. HortScience 39:933937.

Whitaker, B.D. and R.A. Saftner. 2000. Temperaturedependent autoxidation of conjugated trienols from apple peel yields 6-methyl-5-hepten-2one, a volatile implicated in induction of superficial scald. J. Agr. Food Chem. 48:2040 2043.

Whitaker, B.D., J.F. Nock, and C.B. Watkins. 2000. Peel tissue $\alpha$-farnesene and conjugated trienol concentrations during storage of 'White Angel' $\times$ 'Rome Beauty' hybrid apple selections susceptible and resistant to superficial scald. Postharvest Biol. Technol. 20:231241 .
Zanella, A. 2003. Control of apple superficial scald and ripening - a comparison between 1-methylcyclopropene and diphenylamine postharvest treatments, initial low oxygen stress and ultra low oxygen storage. Postharvest Biol. Technol. 27:69-78.

Zanella, A., P. Cazzanelli, A. Panarese, M. Coser, C. Chistè, and F. Zeni. 2005. Fruit fluorescence response to low oxygen stress: Modern storage technologies compared to 1-MCP treatment of apple. Acta Hort. 68:1535-1542.

Zoffoli, J.P., D. Richardson, P. Chen, and D. Sugar. 1998. Spectrophotometric characterization of superficial and senescent scald in pear fruits relative to different stages of maturity. Acta Hort. 475:543-558 